\title{
Constraints from magnetotellurics on the geological structure across a seismic area associated with water wells in the Paraná basin, Brazil
}

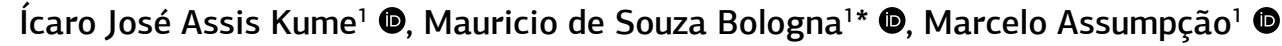

\begin{abstract}
:
The occurrence of earthquakes associated with the opening of groundwater wells is a very rare phenomenon. We present the results from a magnetotelluric profile of about $4 \mathrm{~km}$-long that crosses a seismic zone near the town of Bebedouro, in the Northeastern part of the intra-cratonic Paraná basin, in Brazil. The seismic activity is thought to be caused by a raise in pore-pressure within a fractured basalt aquifer due to the natural injection of water from the shallow aquifer into the basalt. Regularized 2D inversions of the magnetotelluric data show that the basalt layer presents both electric resistivity $(60-300 \mathrm{ohm}-\mathrm{m})$ and thickness $(400-600 \mathrm{~m})$ within the expected ranges for the study area. However, an unforeseen abrupt change $(\sim 200 \mathrm{~m})$ in the basalt thickness has been observed. This variation occurs close to the Western limit of the seismic zone and it nearly coincides with a geoelectric basement deepening of about $600 \mathrm{~m}$. We interpret these lateral contrasts as a fault system that probably controlled the deposition of the Permian to Jurassic volcano-sedimentary sequence under the study area. Our study suggests that a preexisting structure affecting the basement and the basaltic layer is determinant in favoring seismicity associated with the opening of water wells.
\end{abstract}

KEYWORDS: aquifer; conductivity; faults; induced seismicity; basalt.

\section{INTRODUCTION}

Water-induced seismicity is a relatively common phenomenon, such as those associated with reservoir impoundment (e.g., Assumpção et al. 2002, Barros et al. 2018) or injection wells (e.g., Ellsworth 2013). Earthquakes induced by pressure-injection well (mainly for waste disposal) are relatively common (e.g., Rubinstein \& Mahani 2015). However, wells injecting fluids without any additional pressure ("gravity feed wells") may also induce earthquakes (e.g., Rubinstein et al. 2014), but they are less likely to it. Studies of these rarer phenomena or cases of induced seismicity in unusual location are, therefore, highly relevant (Ellsworth 2013).

A few cases of earthquakes induced by the opening of new wells (i.e., gravity feed) have been reported in the intra-cratonic Paraná basin (Yamabe \& Berrocal 1991, Yamabe \& Hamza 1996, Assumpção et al. 2010), in Brazil. In the Bebedouro region (Fig. 1), a long series of earthquakes, with annual cycles from 2004 to 2010, has been attributed to the natural injection

\section{Supplementary material}

Supplementary data associated with this article can be found in the online version: Supplementary Figure A1 and Supplementary Figure A2.

${ }^{1}$ Departamento de Geofísica, Universidade de São Paulo - São Paulo (SP), Brazil.E-mails: icaroxadrez@hotmail.com, mbologna@usp.br, marcelo.iagusp@gmail.com

${ }^{*}$ Corresponding author.

(c) 2019 The autors. This is an open access article distributed under the terms of the Creative Commons license. ("gravity feed") of water from a surface aquifer into a confined aquifer inside a basalt layer pack (Assumpção et al. 2010). By integrating data from the seismic monitoring and temperature logs, Assumpção et al. (2010) explained the observed seismicity and annual cycles, in terms of changing patterns in

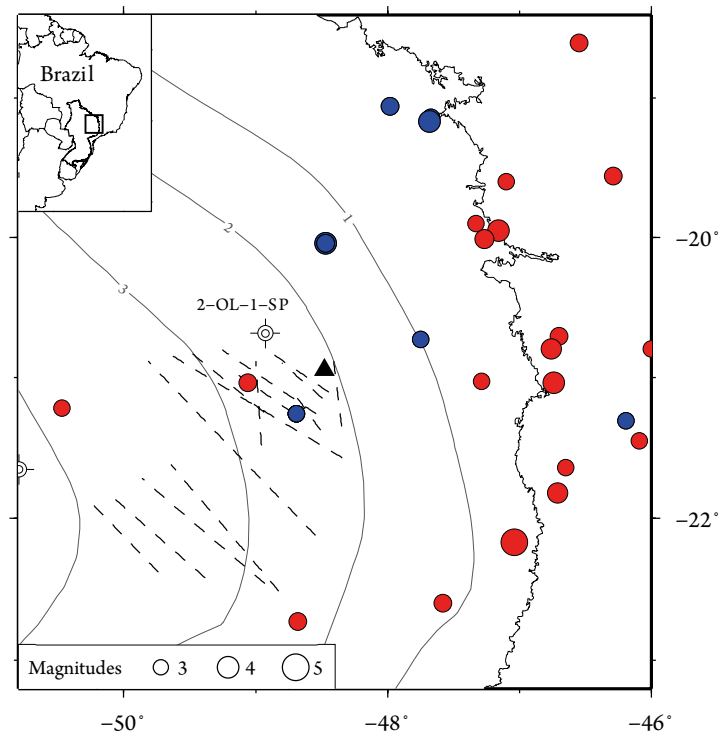

Figure 1. Plot of depth (in kilometers) to the crystalline basement depth and seismicity in the Northeastern Paraná basin. Colored circles are epicenters from the Brazilian catalog. Red and blue circles denote natural and induced earthquakes, respectively. Dashed lines are structural lineaments inferred from land remote sensing data (Amaral 1977). The inset map of Brazil shows the limits of the Paraná Basin (black line) and Figure 1 (black rectangle). 
the groundwater flow within the fractured aquifer, as a consequence of the natural injection of water from the shallow aquifer into the basalt at low pressures.

Thousands of water wells have been drilled in the Paraná basin to exploit confined aquifers in fractured or inter-trap layers in the basalt flows, with no reported seismic activity. This means that very special critical conditions are probably present in the Bebedouro area that would explain the induced earthquakes. Therefore, other geophysical surveys have also been undertaken to enhance knowledge of the study area, including resistivity (Carlos et al. 2012) and time-domain electromagnetic soundings (Porsani et al. 2012). The latter have especially been useful to determine thickness of the shallow sandstone aquifer and variation of electrical resistivity within the upper first hundred meters of the basalt layer in the central-eastern border of the epicenter zone.

We analyzed magnetotelluric (MT) data from five broadband stations along a profile of about $4 \mathrm{~km}$-long crossing the concentration of epicenters in Bebedouro. This paper aims to characterize the basalt and deeper units in a geoelectrical manner and to verify whether there is some association between the mapped electrical structures and the observed seismicity in Bebedouro. The MT method determines the electrical resistivity distribution of the subsurface from the relation between amplitudes of natural transient electric and magnetic fields measured on the surface simultaneously. By using natural fields as signal source, MT soundings can penetrate much deeper (typically up to tens of kilometers or even more) than controlled-source electric and electromagnetic methods (e.g., Chave \& Jones 2012).

This study improves the knowledge on the mechanism of earthquakes in Bebedouro by demonstrating that seismic activity may be favored by the presence of preexisting deep faults. In conjunction with pore pressure elevation in the fractured aquifer, a given fault would enhance the stress level on a critically stressed area as should be the case of the northeastern part of Paraná Basin.

\section{STUDY AREA}

The Bebedouro area, shown in Figure 1, is located in the Northeast part of the intra-cratonic Paraná Basin, which covers the Southern part of Brazil and parts of Argentina, Paraguay and Uruguay (Northfleet et al. 1969). This basin consists of a Paleozoic and Mesozoic sedimentary sequence, evolved from glacial to marine environments and finally to continental conditions, overlain by extensive basaltic lava flows (Serra Geral Formation) erupted in the Lower Cretaceous. In the study area, depth of the geological basement and thickness of lithological units are poorly constrained by sparse wells drilled in the search for hydrocarbons. According to extrapolated data from these wells (Milani 1997), depth to the basement would be in the range from 2,300 to $3,000 \mathrm{~m}$, and the basalt flows would be about $400-600$ thick.

In Bebedouro region, these lava flows are covered by a thin ( 5-120 m) layer of Upper Cretaceous sandstones and siltstones from Bauru Group, which defines a shallow sedimentary aquifer characterized by saturated clayey sand sediments. In addition to this shallow unconfined aquifer, intense groundwater exploitation also occurs in confined fractured aquifers between basalt flows. Seismologically, the Northeastern part of Paraná basin is one of the seismic zones with the largest reservoir-induced events in the country (Assumpção et al.2002).

\section{DATA ACQUISITION AND PROCESSING}

The MT data were acquired using a commercial multi-channel wide band MT system, with about one day of recording. In addition to horizontal components of the electric and magnetic fields (Ex, Ey, $\mathrm{Hx}$ and $\mathrm{Hy}$ ), vertical magnetic fields $(\mathrm{Hz})$ were also computed in each MT station, with $x$-direction aligned to the magnetic meridian $\left(\mathrm{N} 20^{\circ} \mathrm{W}\right)$. The telluric field variations were typically measured with $100-\mathrm{m}$ dipoles configured in a cross, with non-polarizable lead-lead chloride electrodes. The magnetic fields were measured using induction coils for the vertical and two horizontal components. Six sites were occupied during August 2008 on a profile nearly orthogonal to the concentration of epicenters (Fig. 2). Impedance tensors and geomagnetic single station transfer functions were estimated using a robust code (Egbert 1997). Overall, responses are smooth over the period range $0.0008-400 \mathrm{~s}$, except for site 4 (not shown), in which a maximum period of $0.2 \mathrm{~s}$ was achieved. Figure 3 displays two representative sites. The data appear to be of excellent quality, except for some scattering at very short periods in apparent resistivity in site 1 for the $x y$ mode.

Geomagnetic transfer functions are usually represented as induction arrows. We adopted the Parkinson convention in this paper, in which the real part of the arrows point towards current concentrations in enhanced conductivity zones. Figure 4 displays the real components of the induction arrows at four representative periods. At short periods $(<5 \mathrm{~s})$, the arrows have a relatively small amplitude and are almost E-W oriented. This small amplitude is consistent with the fact that the electromagnetic fields are mainly under influence of conductive

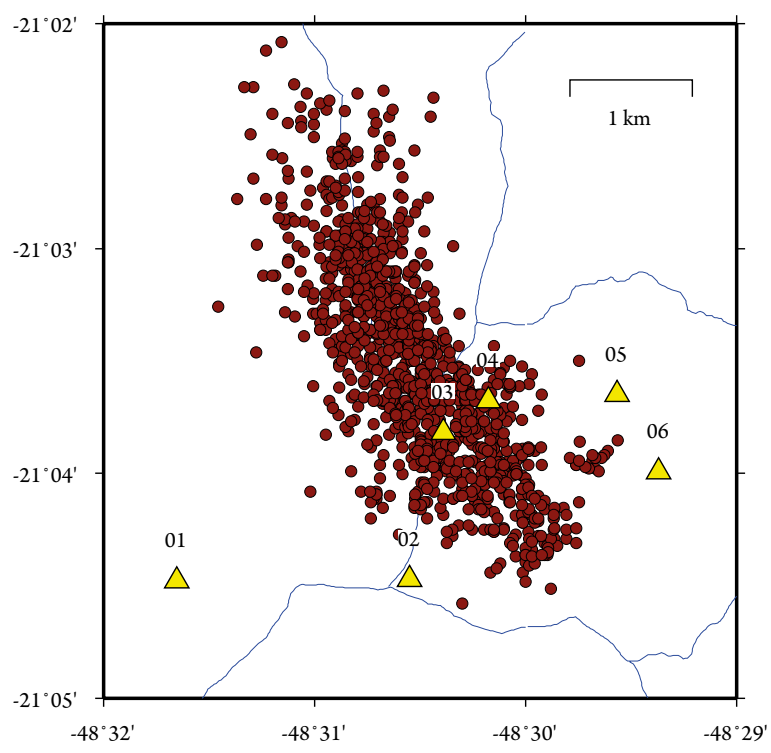

Figure 2. Locations of magnetotelluric stations (solid triangles) superimposed on best-located epicenters of the earthquakes from 2005 to 2008 triggered by water wells opening in the area of Bebedouro district. Streams are represented by blue lines. 

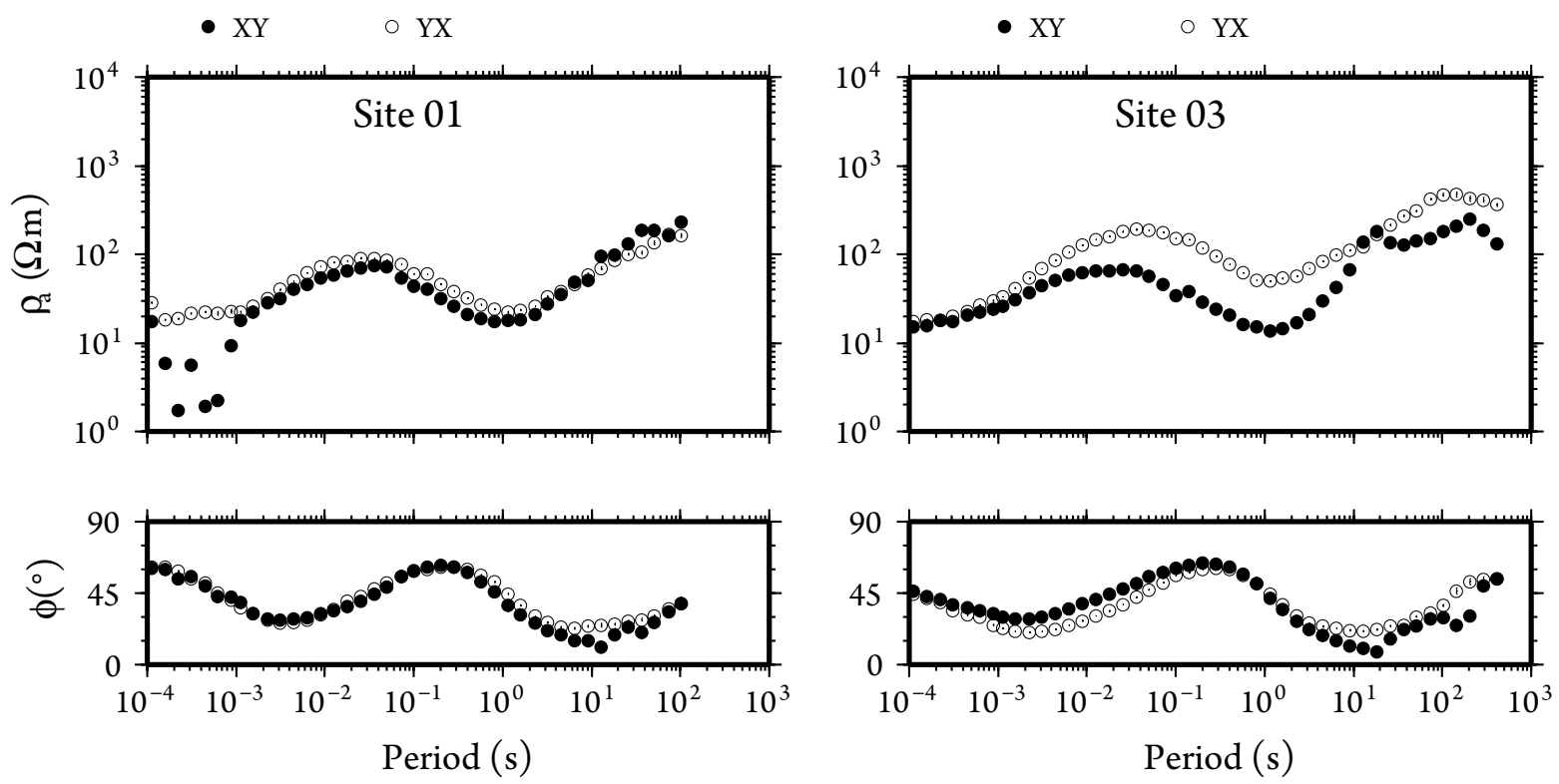

Figure 3. Apparent resistivity and phase responses measured in geomagnetic coordinates (X, North; $\mathrm{Y}$, East) with magnetic declination of $\mathrm{N} 20^{\circ} \mathrm{W}$, at representative sites 1 and 3.
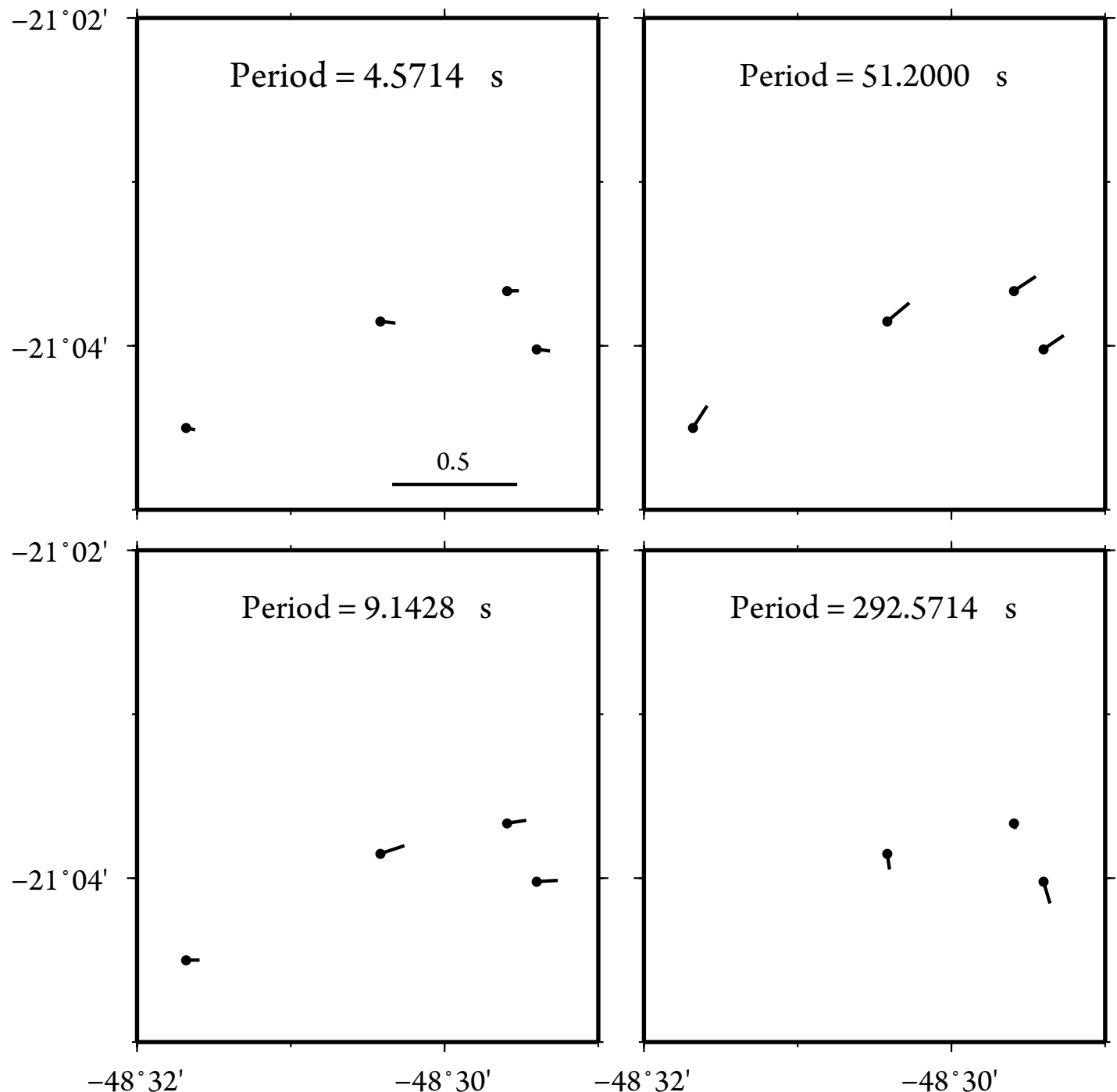

Figure 4. The real induction arrows calculated at four representative periods using Parkinson's convention, in which the arrows point towards lateral resistivity contrast. 
rocks of Paraná basin at such periods. The amplitude of arrows increases (and, therefore, depths) with these increasing periods, and a counterclockwise rotation in their direction is observed in all stations. Arrows become consistently aligned to NE-SW direction, except for the longest periods (>100 s). The general behavior of the induction arrows suggests that shallow and deep structures have different geoelectric strikes.

\section{Geoelectric strike}

We used the tensor decomposition method of Groom and Bailey (1989), extended by McNeice and Jones (2001) to determine the geoelectric strike of regional structures and to estimate the regional two-dimensional (2D) impedance tensors. The process of MT data decomposition is required to determine if the MT site responses are adequately two-dimensional in character. Thus, they can be modeled validly using a $2 \mathrm{D}$ approach. Once the best electrical strike direction is determined, the MT responses at each site are modeled in that coordinate system. Decomposition also removes local-scale electrical distortion from the MT site responses that might obscure the regional 2-D geological response. The Groom-Bailey decomposition assumes that a model of three-dimensional (3D) surficial distortion overlying a $2 \mathrm{D}$ regional conductivity structure ( $3 \mathrm{D} / 2 \mathrm{D}$ model) is valid in a certain period range. Initially, the data sets were subdivided into period bands one decade wide. The best-fitting parameters of period-independent distortion and regional strike were determined within each band. Figure 5 shows the unconstrained strike directions determined in all six sites at four representative period bands. Strikes are almost north-south (or east-west) oriented for short periods $(<1 \mathrm{~s})$, whereas there is a significant counterclockwise rotation in the
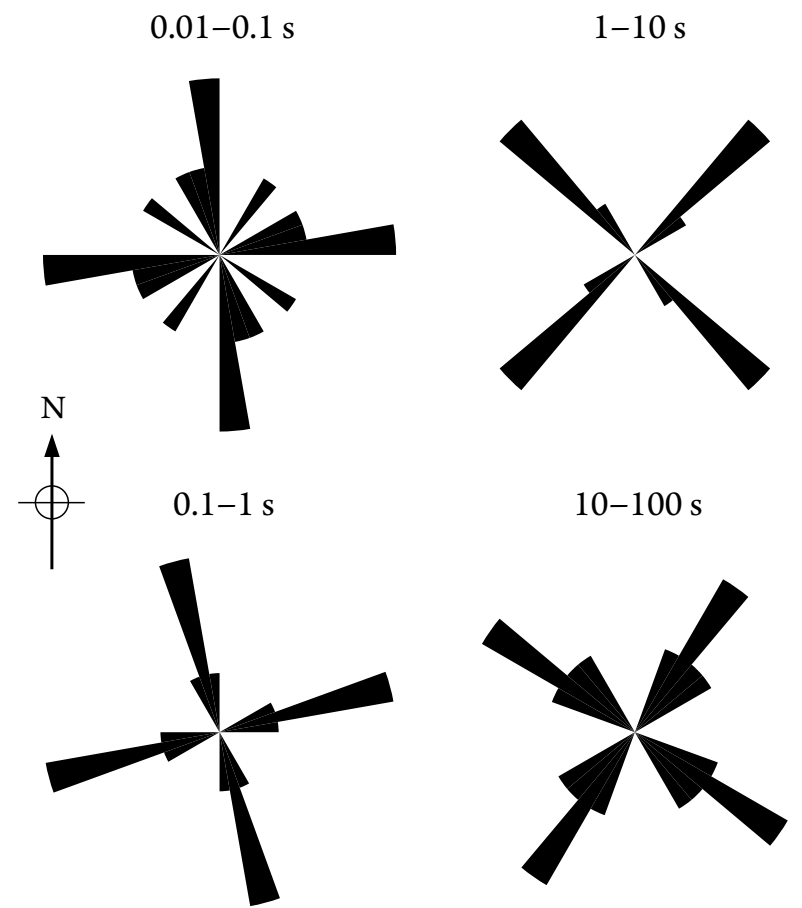

Figure 5. Strike directions using Groom and Bailey (1989) method calculated individually at each period band and site. Four representative period bands of the impedances are examined. Two distinct strikes seem to occur for periods shorter and longer than about $1 \mathrm{~s}$. strike angles for long periods (>1 s). The inherent $90^{\circ}$ ambiguity in the strike determination was solved using information of induction arrows. Considering that arrows must point perpendicular to the geoelectric strike in an ideal 2D structure, the northwest direction seems to be the most plausible orientation for all the strikes. Although this rotation characterizes a $3 \mathrm{D}$ situation generically, the condition for which the $3 \mathrm{D} / 2 \mathrm{D}$ model is valid can be found individually within two or more period intervals (Jones et al. 1993). On our case, the 3D/2D parametrization is thought to be valid in the two intervals separated by the period of about $1 \mathrm{~s}$. Thus, we applied the multisite, multifrequency tensor-decomposition code of McNeice and Jones (2001) to each interval in order to determine the strike angle that best fits all the sites. The resulting strikes for short and long periods were $\mathrm{N} 15^{\circ} \mathrm{W}$ and $\mathrm{N} 41^{\circ} \mathrm{W}$, respectively.

\section{DATA INVERSION}

\section{Simple resistivity-depth transformation}

A first approximation to the true resistivity-depth distribution beneath the recording location can be obtained by applying the Niblett-Bostick transformation (Jones 1983) to the observed apparent resistivity and impedance phases at a site. This transformation is a simple mapping method, in which, in contrast to formal inversion methods, only a single frequency

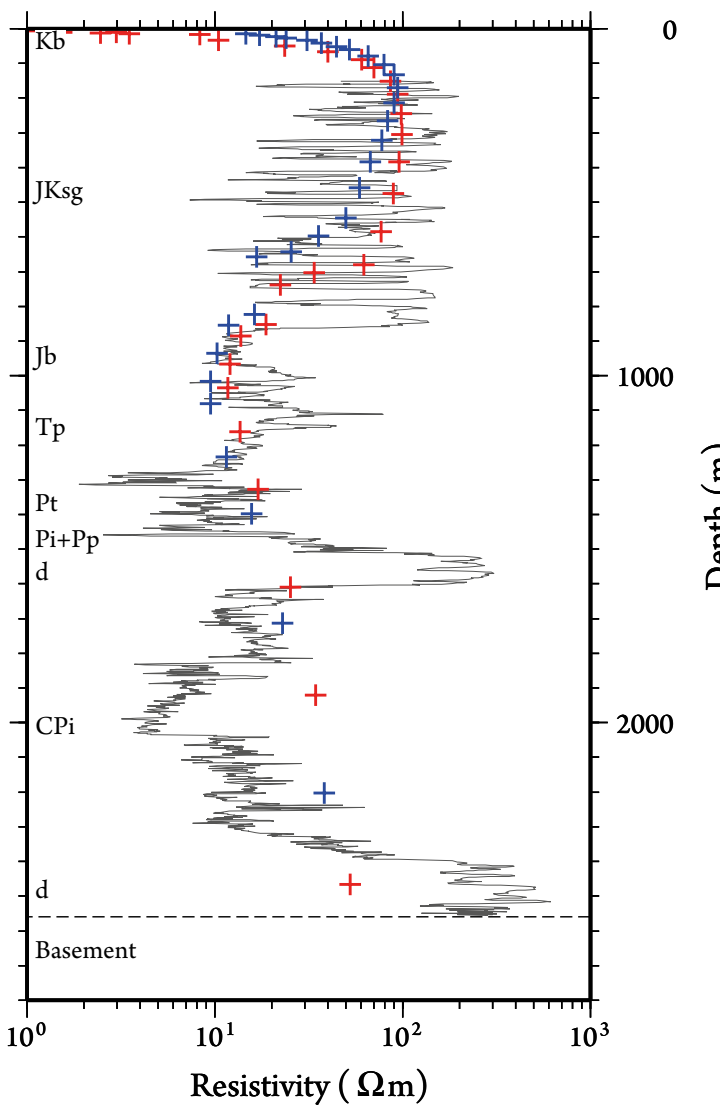

Figure 6. Comparison of the Niblett-Bostick transformation of the transverse electric mode for MT sites 1 and 3 (red and blue crosses, respectively) and resistivity log (black line) for the 1-OL-1-SP well. The left side plots the contact depths of different lithological units: $\mathrm{Kb}$, Bauru Group; Jksg, Serra Geral Formation; Jb, Tp, Pt, PI, and Pp, Permian to Jurassic sedimentary units; $\mathrm{d}$, major diabase intrusions. 
is processed at a time. It is transformed from apparent resistivity and phase against period to layer resistivity against depth using information from the shape of the observed apparent resistivity curves and the skin depth relation. Figure 6 shows the results of the Niblett-Bostick transformation from sites 1 and 3 compared with geological and geophysical information from the 2-OL-1-SP well (see Fig. 1). This comparison is an approximation, because the well is about $50 \mathrm{~km}$ to the northwest of the study area, where the volcano-sedimentary layer is expected to be thicker than around Bebedouro. Nevertheless, the Bauru Group thickness and the resistivities of Serra Geral Formation and underlying sedimentary rocks are well determined in MT data. This good match indicates that the MT data, at least from these two sites, are not significantly distorted by small, near surface resistivity features. Distortions of such nature, called static shift (e.g., Pellerin \& Hohmann 1990), cause vertical displacements of apparent resistivity curves without affecting phases, leading to misleading interpretations, if not considered. Observing all the dataset, we have noticed that the phase curves are similar at the first frequencies of each station, while the level of apparent resistivity curves is almost the same $(20-30 \mathrm{ohm}-\mathrm{m})$. This behavior is another indication of little static distortion in the data.

\section{Adopted procedures in the modeling}

The $2 \mathrm{D}$ resistivity structure of the subsurface in the region of Bebedouro was obtained using the reduced basis Occam's (REBOCC) code of Siripunvaraporn and Egbert (2000). We ran a set of inversions of the decomposed TE and TM apparent resistivities and phases to verify dependences on starting models and inversion parameters. We attributed higher error floors for apparent resistivities than for phases to reduce a possible influence of static shift effects. In some inversions, we strongly reduced the weight of apparent resistivities to virtually invert only the phases. The apparent resistivities recovered in such inversions showed a little level difference in relation to the experimental curves, which is further evidence of low levels of static distortion in the data. The preferred models were obtained with error floors of $20 \%$ for the apparent resistivities and $4 \%$ for phases, using a $100 \mathrm{ohm}-\mathrm{m}$ uniform half-space as starting model. As previously explained, the geoelectric strike varies with period in the study area. Instead of using a single strike, as for example an average of short and long periods, we used two different strikes for better image shallow and deep structures. A similar procedure was adopted, for instance, on the MT data from Southern Canadian Cordillera and Great Slave Lake shear zone (Marquis et al. 1995, Wu et al. 2002).

We used only short periods (0.0001-1.1429 s) at a strike of $\mathrm{N} 15^{\circ} \mathrm{W}$ to image mainly the basalt layer, which is close to the structural alignments of the basalt layer inferred from TDEM data (Porsani et al. 2012). This period range corresponds to penetration depths of about a few meters up to $1.5 \mathrm{~km}$.

\section{Inversion results}

The resulting shallow resistivity model (Fig. 7) fits the apparent resistivity and phase data with a rms of 1.6. A comparison between the data and model responses is shown in Figure 8. We selected data from 0.001 to $51.2 \mathrm{~s}$ and strike of $\mathrm{N} 41^{\circ} \mathrm{W}$ to obtain information of deeper structures of the region, particularly the basin basement. This orientation is very close to the general direction of the epicenters. The final model (Fig. 9) has a global rms of 1.73. A comparison between the data and
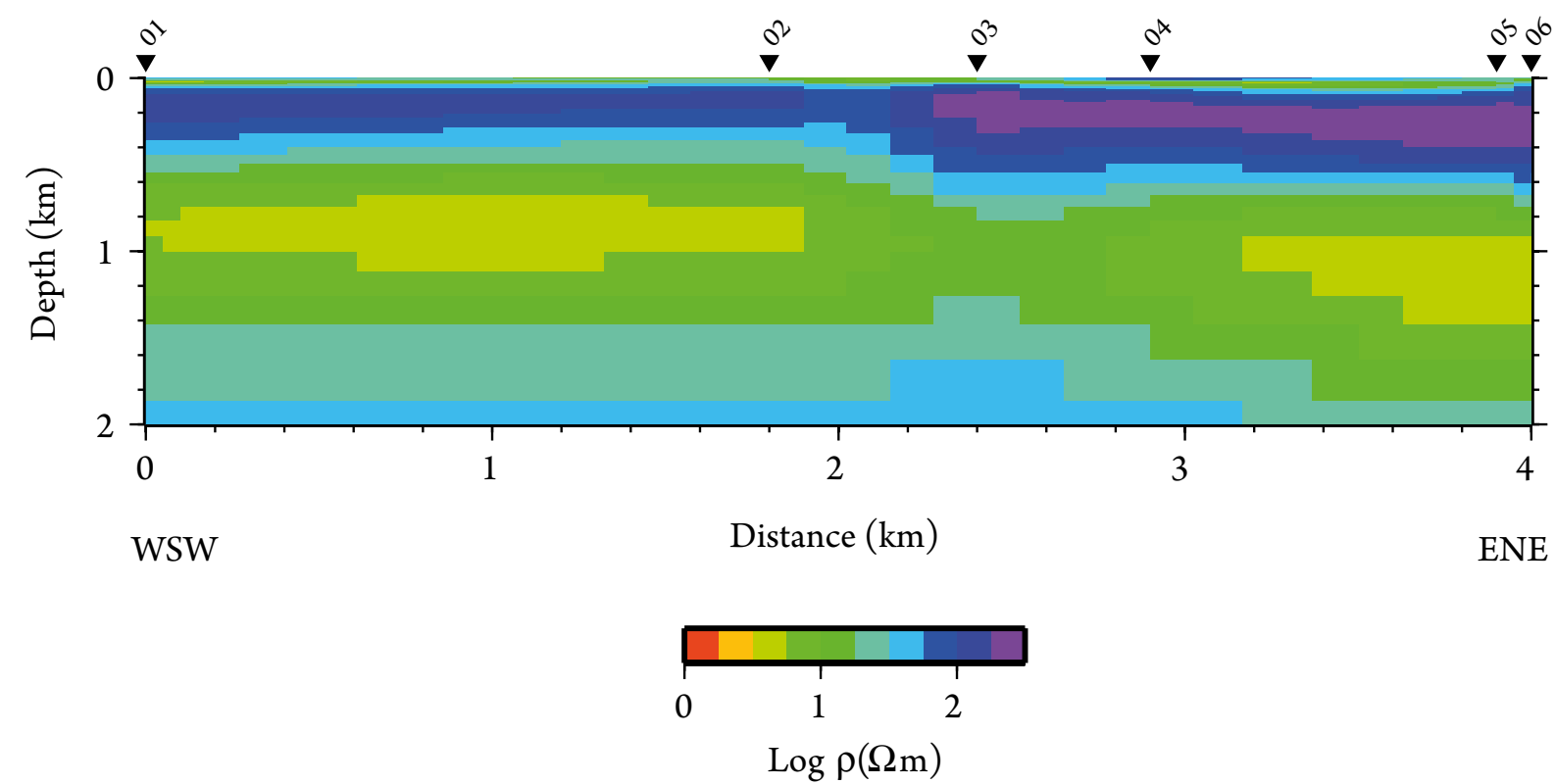

Figure 7. The 2D MT resistivity model obtained by REBOCC inversion using both TE and TM mode distortion-decomposed apparent resistivity and phase data at periods $<1 \mathrm{~s}$ and a regional strike of $\mathrm{N} 15^{\circ} \mathrm{W}$. Error tolerances for apparent resistivities and phases were set at 20 and 4\%, respectively. This model response fits the apparent resistivity and phase data with a rms of 1.69. 
model responses is shown in Figure 10. The most important result from model A is a marked thickness variation of the basalt layer between sites 2 and 3. From West to East, the basalt layer thickness increases from 400 to $600 \mathrm{~m}$. Similar thickening of the basalt layer beneath the seismic zone was also seen in the time-domain electromagnetic surveys (Porsani et al. 2012). Tens of TDEM surveys carried out in the same area showed the basalt layer increasing from about 400-450 $\mathrm{m}$ West of the seismic zone to about 500-650 m towards the East, in which the "step" is in basalt bottom roughly in the middle of the seismic zone, near our station 3 .

The absolute depth to the geological basement is not clearly defined in our resistivity models. The Paraná basin basement is composed of crystalline rocks (usually resistive) and metasedimentary rocks, whose resistivity is more variable. Considering that the oldest sedimentary rocks of the basin can be relatively resistive, the sediment-basement interface can therefore be gradual. In fact, using six MT profiles in the central part of Paraná basin, Stanley et al. (1985) observed a considerable increase in resistivity within the Paleozoic sedimentary package underneath that region, causing the depth to the geoelectric basement to be defined at least $500 \mathrm{~m}$ shallower than the geological basement. In cases like that, the most reliable parameter determined by MT surveys is the basement morphology. In other cases, the geoelectric basement coincides with the top of diabase intrusions that are very close to the geologic basement, as seen in a MT survey (Padilha et al. 1992) that is about $150 \mathrm{~km}$ to the Northwest of Bebedouro. A compilation of the results from Stanley et al. (1985) and Padilha et al. (1992) shows that a resistivity of about $200 \mathrm{ohm}-\mathrm{m}$ is representative of the basin basement. This value is also in agreement with the assumed resistivity for the geoelectric basement of Chaco-Paraná basin in the Northeastern part of Argentina (Favetto et al. 2011). Assuming a resistivity of $200 \mathrm{ohm}-\mathrm{m}$, the basement under Bebedouro is inferred to be in the depth range of 2,900-3,400 m. However, the basement depth varies unevenly along the profile. Between sites 2 and 3 of MT, there is a slight high basement compared with the western segment. The largest variation, however, occurs east of the site 3 , where the depth to the basement increases about $600 \mathrm{~m}$. This variation causes the conductive layer associated with the Permian to Juro-Triassic sedimentary rocks to be thicker in the Eastern portion of the profile. Also, this portion of the sedimentary layer is characterized by resistivities somewhat lower compared with the western portion, which may imply in higher porosity or water salinity.
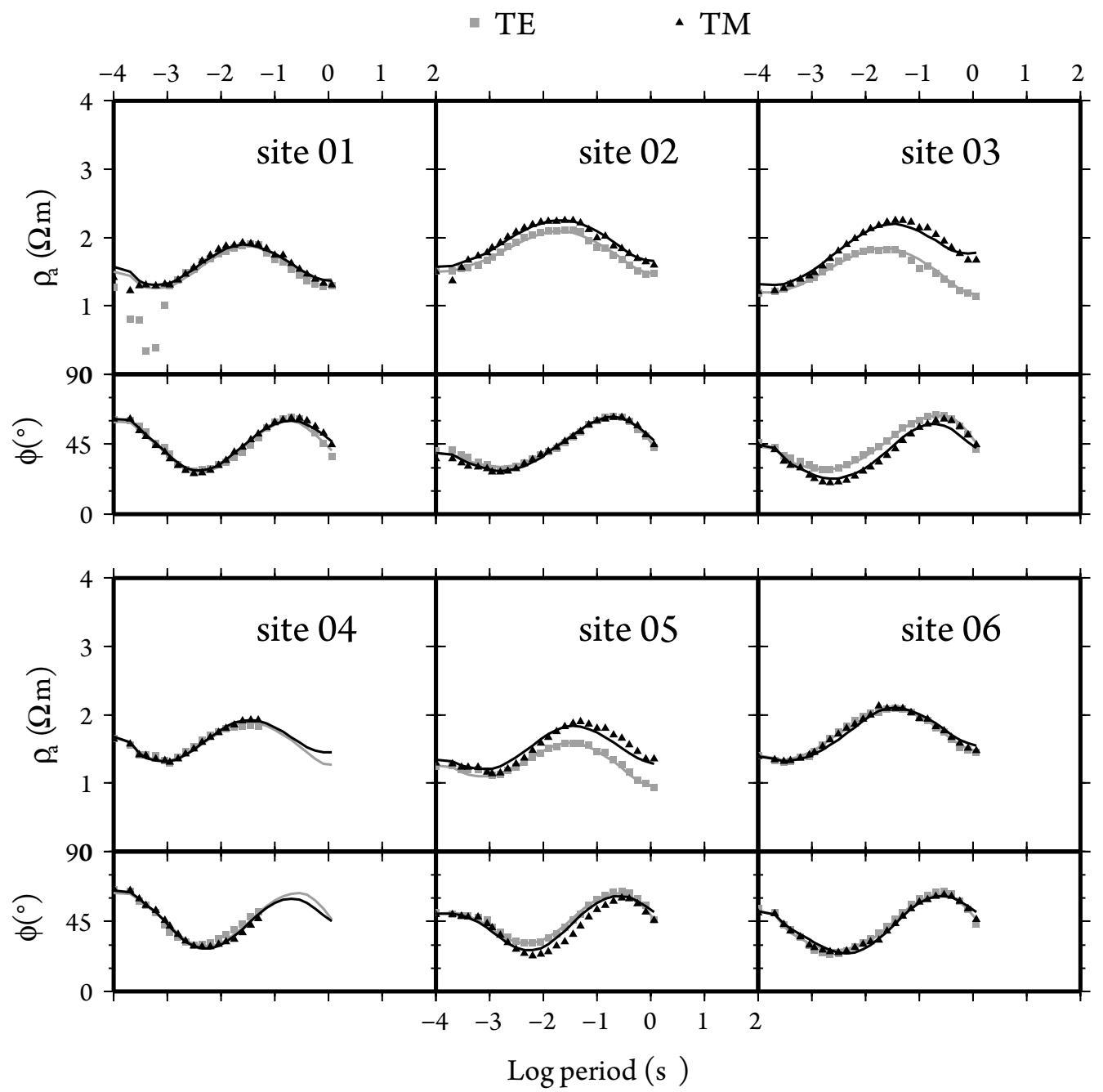

Figure 8. Comparison of observed (symbols) and model (solid lines) apparent resistivity and phase data for the model shown in Figure 7. 


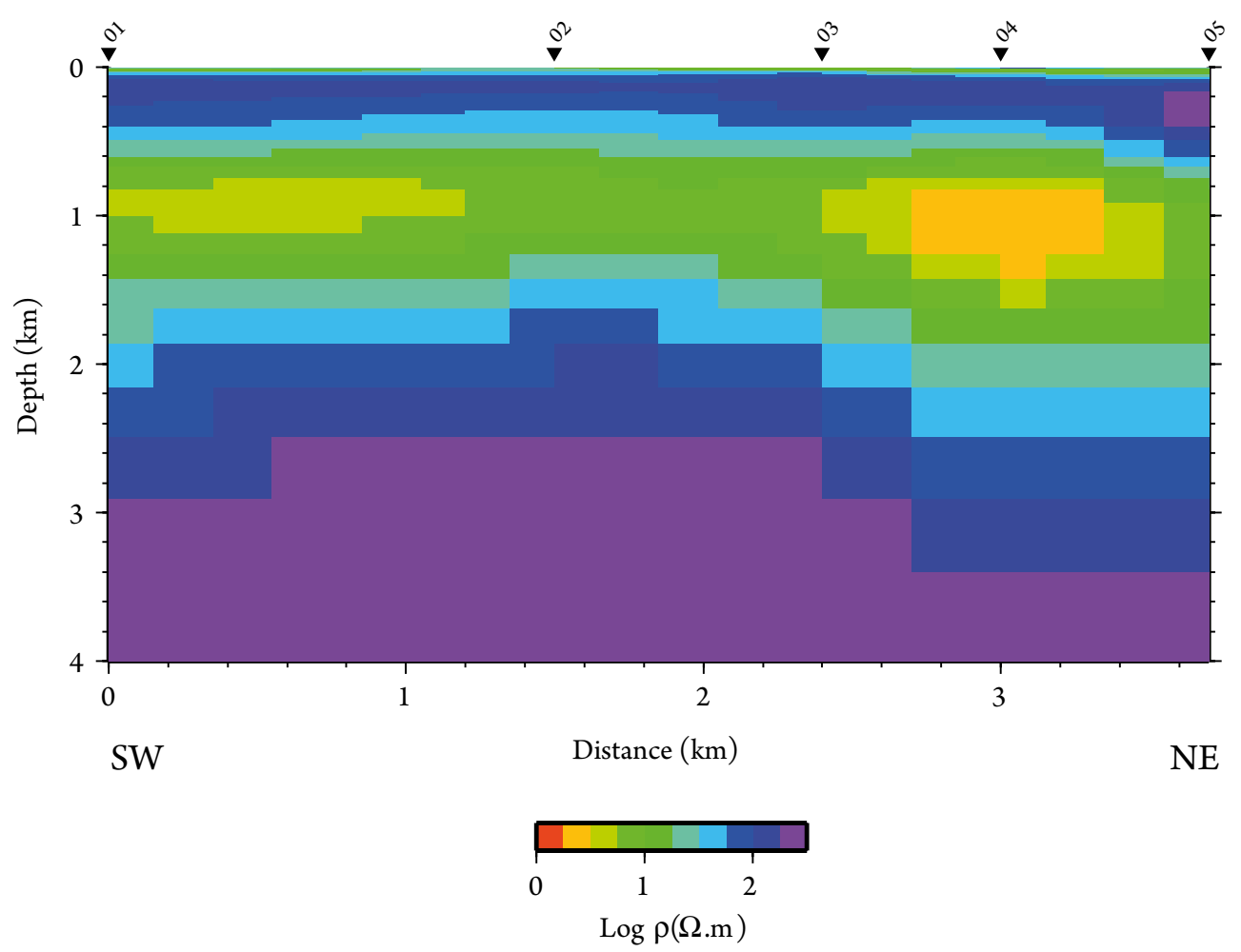

Figure 9. The 2D MT resistivity model obtained by REBOCC inversion using both TE and TM mode distortion-decomposed apparent resistivity and phase data at period range of 0.0001-51.2 $\mathrm{s}$ and a regional strike of $\mathrm{N} 41^{\circ} \mathrm{W}$. Error tolerances for apparent resistivities and phases were set at 20 and 4\%, respectively. This model response fits the apparent resistivity and phase data with a rms of 1.73 .
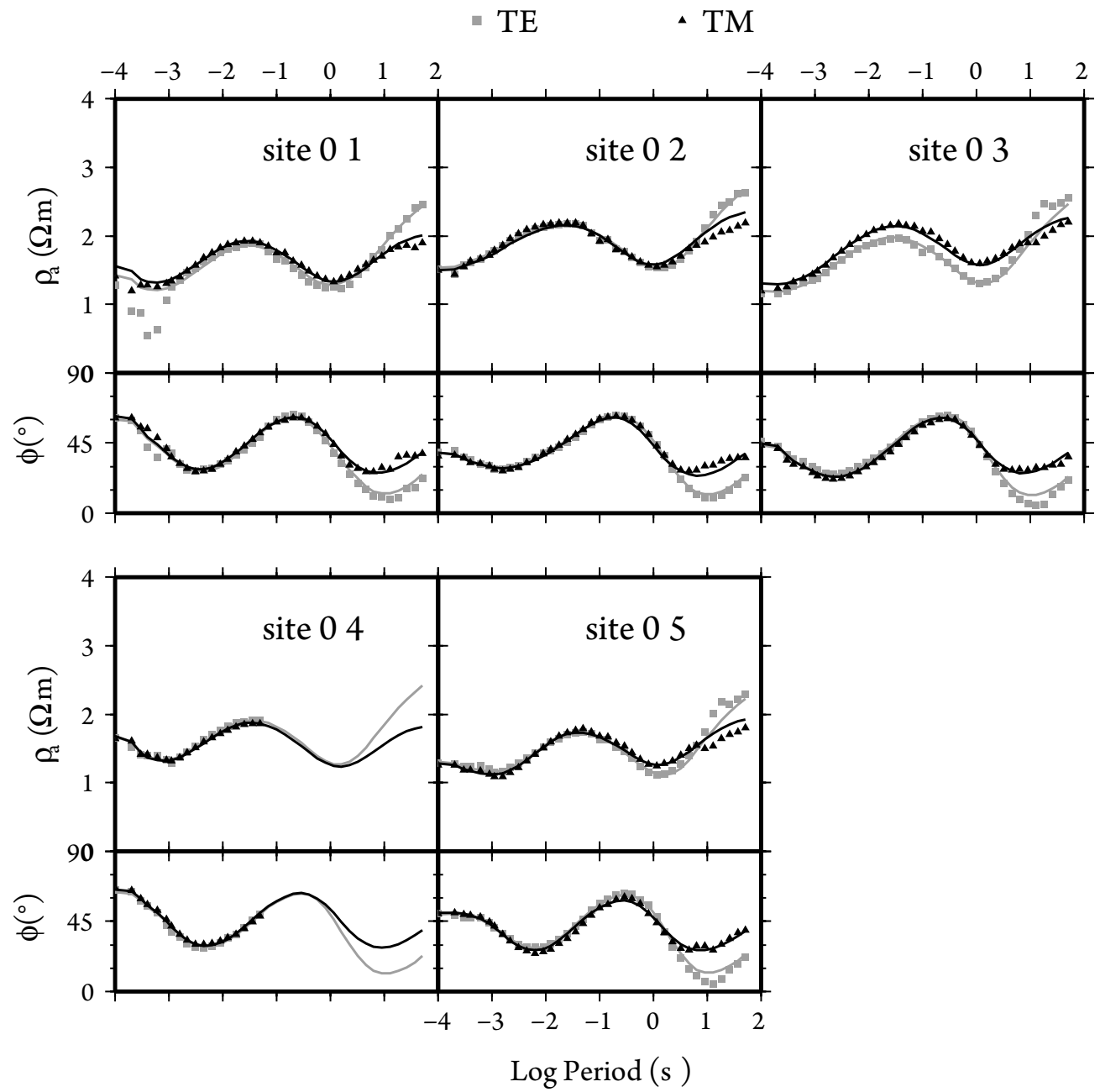

Figure 10. Comparison of observed (symbols) and model (solid lines) apparent resistivity and phase data for the model shown in Figure 9. 


\section{INTERPRETATION}

Resistivity structures in models A and B are consistent with the lithological units expected for the study area. This implies that significant distortions, such as static shift, are either absent or were corrected during inversion. Therefore, magnitude and depth of anomalies are reliably imaged in the resistivity models.

In the top, Bauru Group sandstones are imaged as a thin $(<100 \mathrm{~m})$ horizon with relatively low-resistivity $(<70 \mathrm{ohm}-\mathrm{m})$. The basalt flows of Serra Geral Formation appear as a layer of moderate resistivity $(60-300 \mathrm{ohm}-\mathrm{m})$ overlying a low resistivity region (2-10 ohm-m) corresponding to the Permian to Juro-Triassic sedimentary bottom sequence of Paraná basin. These resistivity ranges are quite similar to those found by TDEM surveys (Porsani et al. 2012). The geoelectric basement of the basin can be inferred by an increase in resistivity, with depth below $2.5 \mathrm{~km}$. In both models, the resistivities associated with each lithological unit are well within the resistivity values observed in other MT studies in the Paraná basin (e.g., Padilha et al. 1992, Bologna et al. 2011, Bologna et al. 2013). They confirm that our data are free from significant distortions.

Assumpção et al. (2010) showed that the inducing mechanism for the earthquakes involved gravity-driven water injection in fractured layers within the basalt pack (such as the confined aquifer formed at inter-trap layers between basalt flows). Given the fact that earthquakes induced by water wells are extremely rare in Paraná basin, one would expect that the basalt layer near the earthquake zone would have some anomalous properties, such as a much higher content of confined aquifers or higher density of fracture zones, to increase the probability of pore pressure, reaching critical values at potential faults. Hence, one would also expect to find lower resistivities in the basalt layer beneath the seismic zone, compared to the aseismic areas. A few of the TDEM inverted resistivity profiles of Porsani et al. (2012) indicated a possible very conductive layer with conductance about 60-80 S within the basalt pack, but probably the MT site spacing did not have enough lateral resolution to detect such narrow $(<100 \mathrm{~m})$ conductive features with top at $\sim 200 \mathrm{~m}$ depth. Our MT inversions indicated a resistive basaltic layer throughout the area, with no measurable resistivity anomaly near the seismic zone. However, our analyses strongly suggest the presence of a regional fault that may be related to the induced seismicity.

The basement depth variation seen in Model B, at first, does not necessarily mean that a corresponding variation should occur in the geological basement. For example, the basement highness could be explained by the presence of diabase intruded into older sediments (e.g., Stanley et al. 1985, Padilha et al. 1992). However, the fact that the basalt layer and the underlying sedimentary units are also thicker toward east supports the existence of a preexisting structure to the deposition of most of the volcano-sedimentary sequence. Indeed, remote sensing images revealed several regional structural lineaments in the Paraná basin (Amaral 1977). Two of them with NNW-SSE and NW-SE orientation are very close to Bebedouro (Fig. 1). The average direction of these inferred regional faults coincides approximately with the $\mathrm{N} 41^{\circ} \mathrm{W}$ geoelectric strike of deep structures and the orientation of the seismic zone.
The general mechanism for inducing earthquakes in pressure-injection wells has been described by Ellsworth (2013) and references therein. The mechanism requires high permeability pathway between a permeable reservoir or aquifer and a fault. In this case, the earthquakes are induced by the increase of pore pressure acting on the fault. However, pre-existing near-critical stresses on the fault are also necessary (otherwise, all wells would induce earthquakes). The occurrence of several cases of reservoir-induced activity in the northeastern part of Paraná basin (Assumpção et al.2002, Barros et al. 2018) suggests that the upper crust in this region is generally under high stresses, which increases the chance that some local areas may be near critical conditions. The normal faulting mechanism determined by Dicelis et al. (2017) is consistent with the hypothesis that the Bebedouro area is under the same regional stress acting in Southern Minas Gerais (E-W compressional and $\mathrm{N}-\mathrm{S}$ extensional stresses) that is thought to be caused mainly by plate-boundary forces and continent-ocean spreading stresses (Assumpção et al. 2016).

We propose an additional local factor to explain the Bebedouro seismicity: pre-existing stress concentration due to a large regional NNW-SSE striking fault, which affects the basement as well as the basalt layer. Strong lateral structural variations and fault intersections are commonly invoked to behave as "stress concentrators" (e.g., Talwani 2014).

Another rare case of seismicity induced by the opening of water wells, in which a regional fault could concentrate stresses, is Nuporanga, situated $80 \mathrm{~km}$ ENE of Bebedouro (Yamabe \& Hamza 1996). In that area, an elongated negative gravity anomaly oriented along the direction NW-SE has been attributed to a thickening of up to $600 \mathrm{~m}$ of Paleozoic sediments under the basaltic lava flows, possibly controlled by local basement features (Bologna \& Ussami 1994).

The induced earthquakes in Bebedouro do not occur in a single major fault, but they occur scattered in a NW-SE oriented zone about $5 \mathrm{~km}$ long $\mathrm{x} 2 \mathrm{~km}$ wide. Hypocentral depths are not well constrained but are within the basaltic layer (Assumpção et al.2010), mostly shallower than $300 \mathrm{~m}$ (Dicelis et al. 2017). Induced seismicity occurs in small fractures in the basalt layer previously under critical stresses, enhanced by the presence of a fault system.

\section{CONCLUSIONS}

The main result obtained from the analysis of our 2D resistivity models is that the basalt layer presents a marked lateral contrast in thickness $(\sim 200 \mathrm{~m})$ near the seismic zone, which is accompanied by increase in the depth of the geoelectric basement of the intra-cratonic Paraná basin. This lateral contrast can be interpreted as a fault that controlled the deposition of the Permian to Jurassic volcano-sedimentary sequence.

We propose this preexisting structure affecting the basement and the basaltic layer to be determinant in favoring the seismicity associated with the opening of water wells. Areas with high crustal stresses, such as the Northeastern part of Paraná basin, and near-critical local stresses due to preexisting structures cutting the basement and basalt layer, are most 
susceptible to the occurrence of induced earthquakes by minor increases in pore pressure from gravity-driven injection.

\section{APPENDIX}

\section{Sensitivity tests}

We have performed sensitivity tests of the most striking features of the model to test data sensitivity regarding the changes in model parameters. It was mainly tested whether both the thickening of the basalt layer and the resistive basement deepening to the west are well constrained by the data. The procedure was undertaken by editing the model, computing the forward response of the modified model, and comparing the results with the measured data.

In the basalt layer test, we extended the depth of this layer between sites 1 and 2 to similar depths in the Eastern part of the model by fixing a number of blocks to $125 \mathrm{ohm}-\mathrm{m}$. The results are displayed in Supplementary Figure A1 for sites 2 and 3. This change clearly misfits the TE and TM mode responses around $0.01 \mathrm{~s}$ at site 2 .
In Supplementary Figure A2, the depth to the basement top is set at 1.6 to $1.7 \mathrm{~km}$, with a constant resistivity value of $80 \mathrm{ohm}-\mathrm{m}$. The forward responses are compared with the observed ones at sites 2 and 5. Such imposition generates a clear mismatch in the observed and modeled responses at $\sim 1 \mathrm{~s}$ at site 5 .

In short, both tested structures are required by the data. At the Western edge of the seismic region, the change in the basalt layer thickness is required to fit the data properly at high frequencies. In addition, deepening of the resistive basement reduces the misfit at intermediate periods in the Eastern part of the model.

\section{ACKNOWLEDGMENTS}

This study was supported by research grants from Fundação de Amparo à Pesquisa do Estado de São Paulo - FAPESP (2007/04325-0) and Conselho Nacional de Desenvolvimento Científico e Tecnológico - CNPq (30.1284/17-2). To the Geomagnetism Group of Instituto Nacional de Pesquisas Espaciais (INPE) for their assistance in fieldwork. To Alan Jones and Gary McNeice for providing their tensor decomposition software.

\section{ARTICLE INFORMATION}

Manuscript ID: 20190032. Received on: 05/08/2019. Approved on: 11/06/2019.

I. A. K. wrote the first draft of the manuscript and prepared all figures of the main part of the manuscript. M. S. B. made sensitivity tests of the models, improved the manuscript through corrections and suggestions, and prepared Supplementary Figures A1 and A2. M. A. provided data on the study area seismicity, revised and improved the manuscript. Competing interests: The authors declare no competing interests.

\section{REFERENCES}

Amaral G. 1977. Padrões fotogeológicos dos litofácies da Formação Bauru do Estado de São Paulo, como observados em imagens LANDSAT. In: Simpósio de Geologia Regional, 1., São Paulo. Resumo Expandido... v. 1, p. 439-449.

Assumpção M., Dias F.L., Zevallos I., Naliboff J.B. 2016. Intraplate stress field in South America from earthquake focal mechanisms. Journal of South American Earth Sciences, 71:278-295. http://doi.org/10.1016/j. jsames.2016.07.005

Assumpção M., Marza V., Barros L., Chimpliganond C., Soares J.E., Carvalho J., Caixeta D., Amorim A., Cabral E. 2002. Reservoir-induced seismicity in Brazil. Pure and Applied Geophysics, 159(1-3):597-617. http:// doi.org/10.1007/pl00001266

Assumpção M., Yamabe T.H., Barbosa J.R., Hamza V., Lopes A.E.V., Balancin L., Bianchi M.B. 2010. Seismic activity triggered by water wells in the Parana Basin, Brazil. Water Resources Research, 46(7):1-11. http://doi. org/10.1029/2009wr008048

Barros L.V., Assumpção M., Ribotta L.C., Ferreira V.M., de Carvalho J.M., Bowen B.M., Albuquerque D.F. 2018. Reservoir-triggered seismicity in Brazil: Statistical characteristics in a midplate environment. Bulletin of the Seismological Society of America, 108(5B), 3046-3061. http://doi. org/10.1785/0120170364

Bologna M.S., Nunes H.O., Padilha A.L., Vitorello I., Pádua M.B. 2013. Anomalous electrical structure in the northwestern Parana Basin, Brazil, observed with broadband magnetotellurics. Journal of South American Earth Sciences, 42:74-82. http://doi.org/10.1016/j.jsames.2012.07.006

Bologna M.S., Padilha A.L., Vitorello I. Pádua M.B. 2011. Signatures of continental collisions and magmatic activity in central Brazil as indicated by a magnetotelluric profile across distinct tectonic provinces. Precambrian Research, 185(1-2):55-64.http://doi.org/10.1016/j.precamres.2010.12.003
Bologna M.S., Ussami N. 1994. Estudo gravimétrico da região de Nuporanga-SP, NE da Bacia do Paraná. In: Congresso Brasileiro de Geologia, 38., Camboriú. Resumo Expandido... v. 1, p. 94-96.

Carlos I.M., Elis V.R., Prado R.L., Porsani J.L. 2012. Métodos geofísicos integrados para a caracterização hidrogeológica dos aquíferos da microbacia Andes, Bebedouro, em São Paulo. Revista Brasileira de Geociências, 42(3):597-614. http://dx.doi.org/10.5327/ Z0375-75362012000300013

Chave A.D. \& Jones A.G. (eds.). 2012. The Magnetotelluric Method: Theory and Practice. Cambridge, Cambridge University Press, $552 \mathrm{p}$.

Dicelis G., Assumpção M., Prado R.L., Agurto-Detzel H., Barbosa E. 2017. Improving the characterization of the seismic source in Bebedouro, Parana Basin, Brazil: further evidence of seismicity triggered by hydraulic stimulation in water wells. Geophysical Journal International, 210(2):594608. http://doi.org/10.1093/gji/ggx180

Egbert G.D. 1997. Robust multiple-station magnetotelluric data processing Geophysical Journal International, 130(2):475-496. http://doi.org/10.1111/ j.1365-246X.1997.tb05663.x

Ellsworth W.L. 2013. Injection-Induced Earthquakes. Science, 341(6142): 1225942. http://doi.org/10.1126/science.1225942

Favetto A., Curcio A., Pomposiello C. 2011. Magnetotellurics applied to the study of the Guarani aquifer in Entre Rios Province, N-E Argentina. Journal of South American Earth Sciences, 32:49-57.

Groom R.W. \& Bailey R.C. 1989. Decomposition of magnetotelluric impedance tensors in the presence of local 3-dimensional galvanic distortion. Journal of Geophysical Research-Solid Earth and Planets, 94(B2):1913-1925. http://doi.org/10.1029/JB094iB02p01913 
Jones A.G. 1983. On the equivalence of the Niblett and Bostick transformation in the magnetotelluric method. Journal of GeophysicsZeitschrift Fur Geophysik, 53:72-73.

Jones A.G., Groom R.W., Kurtz R.D. 1993. Decomposition and Modelling of the BC87 Dataset. Journal of Geomagnetism and Geoelectricity, 45(9):11271150. https://doi.org/10.5636/jgg.45.1127

Marquis G., Jones A.G., Hyndman R.D. 1995. Coincident conductive and reflective middle and lower crust in Southern British Columbia. Geophysical Journal International, 120(1):111-131. http://doi.org/10.1111/j.1365246X.1995.tb05915.x

McNeice G.W. \& Jones A.G. 2001. Multisite, multifrequency tensor decomposition of magnetotelluric data. Geophysics, 66(1):158-173. https://doi.org/10.1190/1.1444891

Milani E.J. 1997. Evolução tectono-estratigráfica da Bacia do Paraná e seu relacionamento com a geodinâmica fanerozóica do Gondwana sul-ocidental. $\mathrm{PhD}$ Thesis, Universidade Federal do Rio Grande do Sul, Porto Alegre, 255 p.

Northfleet A.M., Medeiros R.A., Mühlmann H. 1969. Reavaliação dos dados geológicos da bacia do Paraná. Boletim Técnico da Petrobras, 12 (3):291-346.

Padilha A.L., Trivedi N.B., Vitorello I., Costa J.M. 1992. Upper crustal structure of the northeast Paraná Basin, Brazil, determined from integrated magnetotelluric and gravity measurements. Journal of Geophysical ResearchSolid Earth, 97(B3):3351-3365. http://doi.org/10.1029/91jb02712

Pellerin L., Hohmann G.W. 1990. Transient electromagnetic inversion: A remedy for magnetotelluric static shifts. Geophysics, 55(9):1242-1250. http://doi.org/10.1190/1.1442940

Porsani J.L., Almeida E.R., Bortolozo C.A., Santos F.A.C.M. 2012. TDEM survey in an area of seismicity induced by water wells in Paraná sedimentary basin, Northern São Paulo State, Brazil. Journal of Applied Geophysics, 82:75-83.
Rubinstein J.L. \& Mahani A.B. 2015. Myths and Facts on Wastewater Injection, Hydraulic Fracturing, Enhanced Oil Recovery, and Induced Seismicity. Seismological Research Letters, 86(4):1060-1067. http://doi. org/10.1785/0220150067

Rubinstein J.L., Ellsworth W.L., McGarr A., Benz H.M. 2014. The 2001-Present Induced Earthquake Sequence in the Raton Basin of Northern New Mexico and Southern Colorado. Bulletin of the Seismological Society of America, 104(5):2162-2181. http://doi. org/10.1785/0120140009

Siripunvaraporn W. \& Egbert G. 2000. An efficient data-subspace inversion method for 2-D magnetotelluric data. Geophysics, 65(3):791-803. http:// doi.org/10.1190/1.1444778

Stanley W.D., Saad A.R., Ohofugi W. 1985. Regional Magnetotelluric Surveys in Hydrocarbon Exploration, Parana Basin, Brazil. American Association of Petroleum Geologists Bulletin, 69(3):346-360.

Talwani P. 2014. Unified model for intraplate earthquakes. In: Talwani P. (Ed.). Intraplate Earthquakes. Cambridge, Cambridge. p. e275-e302.

Wu X.H., Ferguson I.J., Jones A.G. 2002. Magnetotelluric response and geoelectric structure of the Great Slave Lake shear zone. Earth and Planetary Science Letters, 196(1-2):35-50. http://doi.org/10.1016/ s0012-821x(01)00594-5

Yamabe T.H. \& Berrocal J. 1991. A origem da atividade sísmica de Presidente Prudente (SP): induzida ou natural? In: Congresso Internacional da Sociedade Brasileira de Geofísica, 2., Salvador. Resumo Expandido... v. 2, p. 521-528.

Yamabe T.H. \& Hamza V.M. 1996. Geothermal investigations in an area of induced seismic activity, northern Sao Paulo State, Brazil. Tectonophysics, 253(3-4):209-225. http://doi. org/10.1016/0040-1951(95)00055-0 